\title{
Effects of Applying Accumulator Straw in Soil on Nutrient Uptake and Soil Enzyme Activity of Capsella bursa-pastoris under Cadmium Stress
}

\author{
Jin Wang ${ }^{1, a}$, Jun Shi ${ }^{2, b}$, Shuting Yang ${ }^{1, c}$ and Xiulan $L^{3, d_{*}}$ \\ ${ }^{1}$ College of Horticulture, Sichuan Agricultural University, Chengdu, Sichuan, China \\ ${ }^{2}$ Mianyang Academy of Agricultural Sciences, Mianyang, Sichuan, China \\ ${ }^{3}$ Institute of Pomology and Olericulture, Sichuan Agricultural University, Chengdu, Sichuan, China \\ awangjin2510@126.com, ${ }^{b}$ tibm@163.com, ${ }^{c} 1250530881 @ q q . c o m,{ }^{d} x$ llvjj@163.com \\ ${ }^{*}$ Corresponding author
}

Keywords: Accumulator straw; Cadmium stress; Capsella bursa-pastoris; Nutrient; Soil enzyme activity

Abstract. The effects of applying four accumulator species (Conyza canadensis, Eclipta prostrate, Nasturtium officinale and Cardamine hirsute) straws in cadmium (Cd) contaminated soil on phosphorus (P) and potassium (K) uptake and soil enzyme activity of Capsella bursa-pastoris were studied through a pot experiment. Five treatments were used in the experiment: control (no straw applied), and straw applied for each of the four plant species (C. canadensis, E. prostrata, $N$. officinale and $C$. hirsuta). When applying the four accumulator species straws, the total $\mathrm{P}$ and $\mathrm{K}$ contents in roots, stems and leaves of $C$. bursa-pastoris increased compared with control. The total $\mathrm{P}$ and $\mathrm{K}$ contents in roots, stems and leaves of $C$. bursa-pastoris were ranked as: $N$. officinale straw $>C$. hirsuta straw $>C$. canadensis straw $>E$. prostrata straw $>$ control. The soil available $\mathrm{P}$ and $\mathrm{K}$ contents were also increased by the four accumulator species straws, which were ranked as: $N$. officinale straw $>C$. hirsuta straw $>C$. canadensis straw $>E$. prostrata straw $>$ control. The four accumulator species straws enhanced soil sucrase and soil urease activities, but reduced soil catalase activity. Therefore, applying accumulator straw could used to increase nutrient content and enhance soil enzyme activity of $C$. bursa-pastoris for the phytoremediation of $\mathrm{Cd}$, and the straw of $N$. officinale was the best.

\section{Introduction}

The crop straw is an important renewable resource in agricultural production [1]. When apply crop straw in farmland soil, the straw will release organic matter, nitrogen, phosphorus, potassium and other nutrients, which can improve the physical and chemical properties of soil, and promote post crop growth [2]. Soil enzyme plays an important role in soil ecosystem, and also is an important index of soil fertility [3]. Capsella bursa-pastoris is a winter Cd-accumulator plant with small biomass, and the phytoremediation efficiency of $\mathrm{Cd}$ is low [4]. In this paper, we applied the straws of Cd-accumulator plants Conyza canadensis [5], Cardamine hirsute [6], Eclipta prostrate [7] and Nasturtium officinale [8] into Cd-contaminated soil and planted C. bursa-pastoris. The aim of the study was to determine if application of straw from the accumulator species could efficiently promote the nutrient uptake and growth of C. bursa-pastoris.

\section{Materials and Methods}

Materials. In August 2013, the shoots of C. canadensis, E. prostrata, $N$. officinale and $C$. hirsuta were collected from the Ya'an campus farm of the Sichuan Agricultural University $\left(29^{\circ} 59^{\prime} \mathrm{N}\right.$, $102^{\circ} 59^{\prime} \mathrm{E}$ ), China, from uncontaminated soil areas. The collected shoots of these plants were dried at $80{ }^{\circ} \mathrm{C}$ to constant weight, finely ground and sieved through a 5-mm-mesh nylon sieve. Capsella bursa-pastoris seedlings with two euphyllas were collected from the Ya'an campus farm (from 
uncontaminated soil) in September 2013. The inceptisol soil samples were collected from Ya'an campus farm in August 2013. The basic properties of the soil were the same as reference [6].

Experimental Design. The experiment was conducted at the Ya'an campus farm from August to October in 2013. The soil samples were air-dried and passed through a 5-mm sieve. Three kilograms of the air-dried soil was weighed into each polyethylene pot $(15 \mathrm{~cm}$ high, $18 \mathrm{~cm}$ in diameter). Cd was added to soils as $\mathrm{CdCl}_{2} \cdot 2.5 \mathrm{H}_{2} \mathrm{O}$ at $50 \mathrm{mg} / \mathrm{kg}$. The pots were soaked in the $\mathrm{Cd}$ solutions for 4 weeks, and then the soil in each pot was mixed with the powdered shoots of the studied plants. Six-gram shoots were applied to each pot ( $2 \mathrm{~g}$ shoots per kg soil), and the soil moisture was maintained at $80 \%$ of field capacity for 1 week. The five experimental treatments in the experiment were control (no straw applied), and straw applied for each of the four plant species (C. canadensis, E. prostrata, $N$. officinale and $C$. hirsuta). Each treatment was replicated three times using a completely randomized design with $10-\mathrm{cm}$ spacing between pots. Four uniform seedlings of C. bursa-pastoris were transplanted into each pot and the soil moisture content was maintained at $80 \%$ of field capacity from the time the plants were transplanted into the pots until the time the plants were harvested. At maturity (after $35 \mathrm{~d}$ ), the entire plants were harvested for determining contents of total $\mathrm{P}$ and $\mathrm{K}$ in roots and shoots [9]. The soil samples were collected for determining soil available $\mathrm{P}$ and $\mathrm{K}$ contents [9] and soil enzyme activity [3].

\section{Results and Discussion}

Total $\mathbf{P}$ content in $\boldsymbol{C}$. bursa-pastoris. When applying the four accumulator species straws in Cd-contaminated soil, the total P contents in roots, stems and leaves of C. bursa-pastoris increased compared with control (Table 1). The total $\mathrm{P}$ contents in roots, stems and leaves of $C$. bursa-pastoris were ranked as: $N$. officinale straw $>C$. hirsuta straw $>C$. canadensis straw $>$ E. prostrata straw $>$ control. Compared with control, applying straws of $C$. canadensis, E. prostrata, $N$. officinale and $C$. hirsuta in soil increased the total P contents in roots of $C$. bursa-pastoris by $5.33 \%(p>0.05), 5.03 \%$ $(p>0.05), 7.10 \%(p>0.05)$ and $6.21 \%(p>0.05)$ respectively, increased by $14.95 \%(p<0.05)$, $11.21 \%(p<0.05), 27.41 \%(p<0.05)$ and $16.20 \%(p<0.05)$ in stems respectively, and increased by $6.11 \%(p<0.05), 3.61 \%(p<0.05), 17.50 \%(p<0.05)$ and $15.00 \%(p<0.05)$ in leaves respectively.

Table 1 Total P content in C. bursa-pastoris

\begin{tabular}{|l|l|l|l|}
\hline Treatments & Roots $(\mathrm{g} / \mathrm{kg})$ & Stems $(\mathrm{g} / \mathrm{kg})$ & Leaves $(\mathrm{g} / \mathrm{kg})$ \\
\hline Control & $3.38 \pm 0.14 \mathrm{a}$ & $3.21 \pm 0.09 \mathrm{c}$ & $3.60 \pm 0.13 \mathrm{~b}$ \\
\hline C. canadensis & $3.56 \pm 0.19 \mathrm{a}$ & $3.69 \pm 0.05 \mathrm{~b}$ & $3.82 \pm 0.07 \mathrm{~b}$ \\
\hline E. prostrata & $3.55 \pm 0.13 \mathrm{a}$ & $3.57 \pm 0.10 \mathrm{~b}$ & $3.73 \pm 0.04 \mathrm{~b}$ \\
\hline N. officinale & $3.62 \pm 0.06 \mathrm{a}$ & $4.09 \pm 0.06 \mathrm{a}$ & $4.23 \pm 0.11 \mathrm{a}$ \\
\hline C. hirsuta & $3.59 \pm 0.15 \mathrm{a}$ & $3.73 \pm 0.12 \mathrm{~b}$ & $4.14 \pm 0.03 \mathrm{a}$ \\
\hline
\end{tabular}

Values are means of three replicate pots. Different lowercase letters indicate significant differences based on one-way analysis of variance in SPSS 13.0 followed by the least significant difference test $(p<0.05)$.

Total $\mathrm{K}$ content in $\boldsymbol{C}$. bursa-pastoris. The same as total $\mathrm{P}$ content in plants, the accumulator straw also increased total $\mathrm{K}$ contents in roots, stems and leaves of $C$. bursa-pastoris (Table 2). The total $\mathrm{K}$ contents in roots, stems and leaves of $C$. bursa-pastoris were ranked as: $N$. officinale straw $>C$. hirsuta straw $>C$. canadensis straw $>$ E. prostrata straw $>$ control. Applying straws of $C$. canadensis, E. prostrata, $N$. officinale and $C$. hirsuta increased the total $\mathrm{K}$ content in roots of $C$. bursa-pastoris by $7.57 \%(p>0.05), 3.16 \%(p>0.05), 13.48 \%(p<0.05)$ and $9.08 \%(p>0.05)$ respectively. Compared with control, the total $\mathrm{K}$ content in stems of $C$. bursa-pastoris was increased by $15.58 \%(p>0.05)$, $5.58 \%(p>0.05), 31.35 \%(p<0.05)$ and $24.23 \%(p>0.05)$ of $C$. canadensis straw, E. prostrata straw, $N$. officinale straw and $C$. hirsuta straw respectively, and increased by $1.70 \%(p>0.05), 0.97 \%(p>$ 
$0.05), 11.77 \%(p<0.05)$ and $7.89 \%(p>0.05)$ of that respectively. So, applying accumulator straw could enhance the $\mathrm{P}$ and $\mathrm{K}$ uptakes of $C$. bursa-pastoris from $\mathrm{Cd}$-contaminated soil.

Table 2 Total K content in C. bursa-pastoris

\begin{tabular}{|l|l|l|l|}
\hline Treatments & Roots $(\mathrm{g} / \mathrm{kg})$ & Stems $(\mathrm{g} / \mathrm{kg})$ & Leaves $(\mathrm{g} / \mathrm{kg})$ \\
\hline Control & $7.27 \pm 0.14 \mathrm{~b}$ & $5.20 \pm 0.11 \mathrm{~d}$ & $8.24 \pm 0.30 \mathrm{c}$ \\
\hline C. canadensis & $7.82 \pm 0.31 \mathrm{ab}$ & $6.01 \pm 0.34 \mathrm{bc}$ & $8.38 \pm 0.17 \mathrm{bc}$ \\
\hline E. prostrata & $7.50 \pm 0.40 \mathrm{ab}$ & $5.49 \pm 0.28 \mathrm{~cd}$ & $8.32 \pm 0.16 \mathrm{bc}$ \\
\hline N. officinale & $8.25 \pm 0.35 \mathrm{a}$ & $6.83 \pm 0.13 \mathrm{a}$ & $9.21 \pm 0.27 \mathrm{a}$ \\
\hline C. hirsuta & $7.93 \pm 0.10 \mathrm{ab}$ & $6.46 \pm 0.20 \mathrm{ab}$ & $8.89 \pm 0.21 \mathrm{ab}$ \\
\hline
\end{tabular}

Values are means of three replicate pots. Different lowercase letters indicate significant differences based on one-way analysis of variance in SPSS 13.0 followed by the least significant difference test $(p<0.05)$.

Soil available $\mathbf{P}$ content. When applying the four accumulator species straws in Cd-contaminated soil, the soil available P content increased compared with control (Fig. 1). The soil available P content was ranked as: $N$. officinale straw $>C$. hirsuta straw $>C$. canadensis straw $>$ E. prostrata straw $>$ control. Compared with control, the soil available P content of applying $C$. canadensis straw, $E$. prostrata straw, $N$. officinale straw and $C$. hirsuta straw increased by $8.40 \%(p>0.05), 2.28 \%(p>$ $0.05), 20.54 \%(p<0.05)$ and $13.96 \%(p<0.05)$ respectively.

Soil available $\mathrm{K}$ content. The soil available K content increased compared with control when applying the four accumulator species straws in Cd-contaminated soil (Fig. 2). The soil available K content was also ranked as: $N$. officinale straw $>C$. hirsuta straw $>C$. canadensis straw $>$ E. prostrata straw > control. Compared with control, the soil available $\mathrm{K}$ content of applying $C$. canadensis straw, E. prostrata straw, N. officinale straw and C. hirsuta straw increased by $3.64 \%(p>0.05), 0.84 \%(p>$ $0.05), 15.78 \%(p<0.05)$ and $10.62 \%(p<0.05)$ respectively.

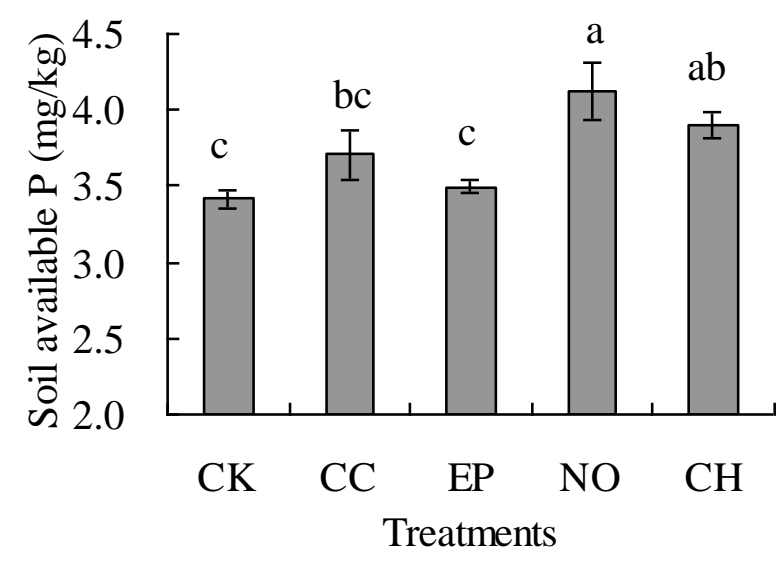

Fig. 1 Soil available K. Values are means of three replicate pots. Different lowercase letters indicate significant differences based on one-way analysis of variance in SPSS 13.0 followed by the least significant difference test $(p<0.05) . \mathrm{CK}=$ control, $\mathrm{CC}=C$. canadensis, $\mathrm{EP}=$ E. prostrata, $\mathrm{NO}=N$. officinale, $\mathrm{CH}$ $=C$. hirsuta.

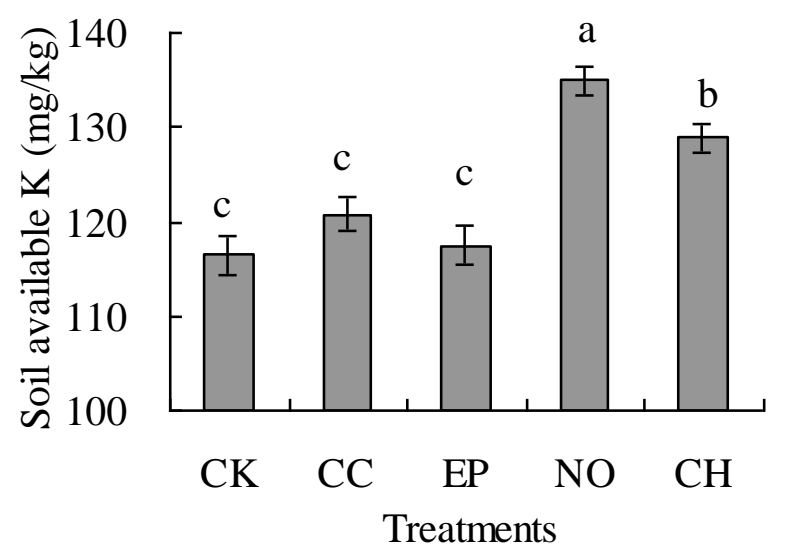

Fig. 2 Soil available K. Values are means of three replicate pots. Different lowercase letters indicate significant differences based on one-way analysis of variance in SPSS 13.0 followed by the least significant difference test $(p<0.05)$. $\mathrm{CK}=$ control, $\mathrm{CC}=C$. canadensis, $\mathrm{EP}=$ E. prostrata, $\mathrm{NO}=N$. officinale, $\mathrm{CH}$ $=C$. hirsuta . 
Soil enzyme activity. The four accumulator species straws enhanced soil sucrase and soil urease activities of Cd-contaminated soil, but reduced soil catalase activity (Table 3). The soil sucrase activity was ranked as: $C$. canadensis straw $>C$. hirsuta straw $>N$. officinale straw $>$ E. prostrata straw $>$ control, soil urease activity was ranked as: $N$. officinale straw $>C$. hirsuta straw $>C$. canadensis straw $>$ E. prostrata straw $>$ control, and soil catalase activity was ranked as: control $>E$. prostrata straw $>C$. canadensis straw $>C$. hirsuta straw $>N$. officinale straw. Compared with control, applying $C$. canadensis straw, $E$. prostrata straw, $N$. officinale straw and $C$. hirsuta straw enhanced soil sucrase activity by $96.20 \%(p<0.05), 8.86 \%(p<0.05), 18.57 \%(p<0.05)$ and $43.25 \%(p<0.05)$ respectively, and soil urease activity enhanced by $157.02 \%(p<0.05), 69.36 \%(p<0.05), 191.91 \%(p$ $<0.05)$ and $186.81 \%(p<0.05)$ respectively, and soil catalase activity reduced by $2.19 \%(p>0.05)$, $1.46 \%(p>0.05), 15.69 \%(p<0.05)$ and $9.85 \%(p<0.05)$ respectively.

Table 3 Soil enzyme activity

\begin{tabular}{|l|c|c|c|}
\hline \multicolumn{1}{|c|}{ Treatments } & Soil sucrase activity $(\mathrm{mg} / \mathrm{g})$ & Soil urease activity $(\mathrm{mg} / \mathrm{g})$ & Soil catalase activity $(\mathrm{ml} / \mathrm{g})$ \\
\hline CK & $0.474 \pm 0.006 \mathrm{~d}$ & $0.235 \pm 0.010 \mathrm{~d}$ & $0.274 \pm 0.011 \mathrm{a}$ \\
\hline C. canadensis & $0.930 \pm 0.008 \mathrm{a}$ & $0.604 \pm 0.016 \mathrm{~b}$ & $0.268 \pm 0.007 \mathrm{ab}$ \\
\hline E. prostrata & $0.516 \pm 0.036 \mathrm{~d}$ & $0.398 \pm 0.013 \mathrm{c}$ & $0.270 \pm 0.008 \mathrm{ab}$ \\
\hline N. officinale & $0.562 \pm 0.005 \mathrm{c}$ & $0.686 \pm 0.008 \mathrm{a}$ & $0.231 \pm 0.013 \mathrm{c}$ \\
\hline C. hirsuta & $0.679 \pm 0.009 \mathrm{~b}$ & $0.674 \pm 0.018 \mathrm{a}$ & $0.247 \pm 0.006 \mathrm{bc}$ \\
\hline
\end{tabular}

Values are means of three replicate pots. Different lowercase letters indicate significant differences based on one-way analysis of variance in SPSS 13.0 followed by the least significant difference test $(p<0.05)$.

\section{Conclusions}

When applying the four accumulator species (C. canadensis, E. prostrata, $N$. officinale and C. hirsuta) straws in $\mathrm{Cd}$-contaminated soil, the total $\mathrm{P}$ and $\mathrm{K}$ contents in roots, stems and leaves of $C$. bursa-pastoris increased compared with control. The total $\mathrm{P}$ and $\mathrm{K}$ contents in roots, stems and leaves of $C$. bursa-pastoris were ranked as: $N$. officinale straw $>C$. hirsuta straw $>C$. canadensis straw $>E$. prostrata straw $>$ control. The soil available $\mathrm{P}$ and $\mathrm{K}$ contents were also increased by the four accumulator species straws, which were ranked as: $N$. officinale straw $>C$. hirsuta straw $>C$. canadensis straw $>E$. prostrata straw $>$ control. The four accumulator species straws enhanced soil sucrase and soil urease activities, but reduced soil catalase activity. Therefore, applying accumulator straw could used to increase nutrient content and enhance soil enzyme activity of C. bursa-pastoris in Cd-contaminated soil.

\section{References}

[1] Y.Y. Shen and H. Chen: Chinese Agricultural Science Bulletin Vol. 25 (2009), p. 291.

[2] Y.H. Jiang, Z.R. Yu and Y.L. Ma: Vol. 32 (2001), p. 209.

[3] L.K. Zhou: Soil Enzymology (Science Press, Beijing 1987).

[4] Y. Liu, L. Lin, Q. Jin and X. Zhu: Environmental Progress \& Sustainable Energy Vol. 34 (2015), p. 663.

[5] S. Wei, Q. Zhou, U.K. Saha, H. Xiao, Y. Hu, L.P. Ren and P. Gu: Journal of Hazardous Materials Vol. 163 (2009), p. 32.

[6] L. Lin, J. Shi, Q. Liu, M. Liao and L. Mei: Environmental Monitoring and Assessment Vol. 186 (2014), p. 4051. 
[7] L. Luo, L.J. Lin, M.A. Liao, X. Zhang and D.Y. Yang: Acta Agriculturae Boreali-Sinica Vol. 29 (2014), p. 216.

[8] L.J. Lin, L. Luo, M.A. Liao, X. Zhang and D.Y. Yang: Resources and Environment in the Yangtze Basin Vol. 24 (2015), p. 684.

[9] S.D. Bao: Agrochemical Soil Analysis ( $3^{\text {rd }}$ edition, China Agriculture Press, Beijing 2000). 